\title{
AOR
}

Selected Papers of \#AolR2019: The $20^{\text {th }}$ Annual Conference of the Association of Internet Researchers Brisbane, Australia / 2-5 October 2019

\section{IN EACH OTHER WE (STRATEGICALLY) TRUST: THE DISCURSIVE NETWORKS OF TRUST IN TWITTER DISCUSSIONS OF IMMIGRATION IN AUSTRALIA}

\author{
Ehsan Dehghan \\ Digital Media Research Centre, Queensland University of Technology
}

\section{Introduction}

This study investigates the discourses around the topic of immigration in the Australian Twittersphere, especially with regards to the discursive role of trust in the dynamics of the debates. Being a predominantly immigrant country, with approximately a third of its population born overseas, Australia has always been engaged with discussions about immigration in one form or another. In recent years, these discussions have revolved around the immigration policies of the country and its treatment of refugees and asylum seekers in offshore detention camps. Furthermore, the discourse of immigration in Australia has also been influenced by the global rise of anti-immigration discourses, and the so-called 'refugee crisis' in Europe.

The data for this project was collected using TrISMA-The Tracking Infrastructure for Social Media Analysis-which is an ongoing collection of tweets by Australian Twitter users (Bruns et al., 2016). I used a range of immigration-related keywords, phrases, and hashtags to collect a corpus of 1,029,156 tweets posted between February and October 2018. The keywords used for the data collection were chosen so they cover a range of different perspectives and discourses about immigration, such as generic discussions of the topic, debates over offshore detention camps, anti-immigration sentiments, and so on. This study employs a mixed-methods approach, drawing from social media analytics, network analysis, corpus linguistics, and discourse analysis. The analysis starts from the broader communicative patterns and practices (e.g. use of hashtags, link-sharing patterns, etc.) to provide a bird's-eye view of the discursive environment. Following this, I employ social network analysis to identify the networked publics and the discourses involved in the debate, and examine the flows of information between the identified clusters. Upon identifying the various communities and discourses, I perform a qualitative analysis of tweets posted by each community, first using keyword Suggested Citation (APA): Dehghan, E. (2019, October 2-5). In each other we (strategically) trust: The discursive networks of trust in Twitter discussions of immigration in Australia. Paper presented at AolR 2019: The $20^{\text {th }}$ Annual Conference of the Association of Internet Researchers. Brisbane, Australia: AolR. Retrieved from http://spir.aoir.org. 
analysis (Baker, 2004) to identify the salient features, themes and topics in each discourse, and then investigating subsets of tweets by each community from a discourse-analytical and discourse-theoretical (Carpentier \& De Cleen, 2007) perspective. To further supplement the classification of accounts and discourse communities, this project draws from the clusters of users identified in the map of the Australian Twittersphere, which is a network analysis of follower/followee relationships among approximately 250,000 best globally connected Australian Twitter users (Bruns, Moon, Münch, \& Sadkowsky, 2017).

\section{Findings}

With regards to information sources disseminated in the dataset, the examination of URLs posted in the dataset points to the presence of divergent patterns in link-sharing by the various communities involved in the debate. Although mainstream and wellestablished media outlets are shared by the majority of accounts in the dataset, the more explicitly partisan discourse communities in the Australian Twittersphere, such as the clusters of 'progressive politics' and 'hard-right politics' (Bruns, 2017), rely more on information sources with more explicit political leanings. The cluster of hard-right accounts, for instance, widely disseminates links to media outlets and websites such as Breitbart, Infowars, Sputnik News, and anti-Islam websites such as JihadWatch. On the other hand, there is a high level of sharing URLs to left-leaning outlets (Hurcombe, Burgess, \& Harrington, 2018; Park, Fisher, Fuller, \& Lee, 2018) such as Buzzfeed, Junkee, and The Guardian among the 'progressive politics' cluster. Although this finding cannot conclusively point to users' trust in certain information sources, it could potentially indicate the strategic performance of trust, through which users decide to share certain links, and avoid circulating others. Pew center's survey similarly shows how at times users share disinformation despite knowing what they are sharing is fake (Mitchell, Barthel, \& Holcomb, 2016).

The same partisanship is also evident from the range of secondary hashtags used by the various communities involved in the discussion. Although all communities use the more topical and broader hashtags in their discussions (e.g. \#AusPol or Australian Politics, \#Immigration, etc.), they often juxtapose these with the more explicitly partisan discourse markers, such as \#BringThemHere (hashtag used in the campaign against offshore detention camps) or \#StopTheBoats (hashtag used in support of the detention camps). Additionally, secondary hashtags are also used interdiscursively to recontextualize different discourses vis-à-vis the debate over immigration in Australia. For instance, the 'progressive politics' cluster almost exclusively focuses on domestic issues, such as the offshore detention camps, indigenous rights, and other political issues in Australia. On the other hand, the 'hard-right community' extensively uses hashtags referring to international contexts, such as the refugee crisis in Europe, Donald Trump's travel ban and/or US-Mexico wall, and the like.

Examining the networks of retweets and @mentions, it is evident that Twitter users strategically choose their own 'crowd-sourced elites' (Papacharissi, 2015) as opinion leaders and curators of the debate. In this sense, each discourse community amplifies their discourse through giving more visibility to the tweets and users they collectively trust as their opinion leaders on the platform. However, collectives of users also actively 
form alliances with other discourses involved in the broader discursive environment, through the use of affordances of Twitter, such as retweets. For the 'progressive politics' community, for instance, these strategic alliances form through retweeting actors from the indigenous-rights and law communities, and international public figures promoting refugee rights. On the other hand, the 'hard-right politics' cluster actively engages with well-known international ultra-conservative and far-right figures, in order to amplify their voice and interdiscursively connect their political stance with the broader global discursive environment.

Qualitative investigation of the discourse of each community also supports the findings of the previous stages of the analysis. Each community in the debate draws from their own discourses, symbolic resources, and perspectives in their argumentation regarding the topic of immigration. This often involves interdiscursive references to other topics and discourses perceived as relevant to the notion of immigration by each community. While the 'progressive politics' cluster frames the topic from the perspective of human rights and focuses on closing offshore detention camps, the 'law' cluster intensifies the legal aspects of the discussion, focusing on how the treatment of refugees in the offshore detention camps is unconstitutional. On the other hand, the hard-right community often brings the discourses of terrorism and national security to the front, arguing for stricter immigration and asylum policies, usually from an anti-Islam perspective. Interdiscursive references to Islam and terrorism are frequently present in the discourse of the hard-right, while they are almost absent from the discourse of other communities in the dataset.

\section{Conclusions}

Overall, this study shows the complexities involved in considering the notion of 'trust' in the social media environment. The findings of this research show how the act of trusting is in itself a discursive strategy, in that users strategically choose what and who to trust, whose discourse to amplify, and which actors to actively avoid. Using the affordances of the platform, users form calculated networks of discursive alliances to form an agonistic space (Mouffe, 2013) within which they can amplify their voice, while at the same time maintaining their antagonism (Laclau \& Mouffe, 2001) against the rival discourses.

\section{References}

Baker, P. (2004). Querying Keywords: Questions of Difference, Frequency, and Sense in Keywords Analysis. Journal of English Linguistics, 32(4), 346-359.

Bruns, A. (2017). Echo chamber? What echo chamber? Reviewing the evidence. 6th Biennial Future of Journalism Conference.

Bruns, A., Burgess, J., Banks, J., Tjondronegoro, D., Dreiling, A., Hartley, J., ... Sadkowsky, T. (2016). TrISMA: Tracking Infrastructure for Social Media Analysis.

Bruns, A., Moon, B., Münch, F., \& Sadkowsky, T. (2017). The Australian Twittersphere in 2016: Mapping the Follower/Followee Network. Social Media+ Society, 3(4),. 
Carpentier, N., \& De Cleen, B. (2007). Bringing discourse theory into media studies: The applicability of discourse theoretical analysis (DTA) for the study of media practises and discourses. Journal of Language and Politics, 6(2), 265-293.

Hurcombe, E., Burgess, J., \& Harrington, S. (2018). What's newsworthy about 'social news'?: Characteristics and potential of an emerging genre. Journalism.

Laclau, E., \& Mouffe, C. (2001). Hegemony and socialist strategy: Towards a radical democratic politics (2nd ed). London; New York: Verso.

Mitchell, A., Barthel, M., \& Holcomb, J. (2016, December 15). Many Americans Believe Fake News Is Sowing Confusion | Pew Research Center. Retrieved February 26, 2019, from http://www.journalism.org/2016/12/15/many-americans-believe-fake-news-issowing-confusion/

Mouffe, C. (2013). Agonistics: Thinking the World Politically. Verso.

Papacharissi, Z. (2015). Affective publics: Sentiment, technology, and politics. Oxford; New York, NY: Oxford University Press.

Park, S., Fisher, C., Fuller, G., \& Lee, J. Y. (2018). Digital News Report: Australia 2018. News \& Media Research Centre, University of Canberra. 